\title{
THE EFFECT OF GENDER ON FINANCIAL LITERACY ${ }^{1}$ CINSIYYETIN FİNANSAL OKURYAZARLIĞA ETKİSI
}

\begin{abstract}
Haşim $B A \breve{G} C I^{2}$
Yunus Emre KAHRAMAN

Abstract

Financial literacy is the ability of an individual to take informed decisions on basic financial practices. Financial literacy is essential not only for the individual but also for the development of the markets of a country. In order to develop the markets of a country, education has to be provided to everyone starting from the individuals with the lowest position. Thus, providing quality finance education contributes to the development of both the individual and the economy of the concerned country.

This study investigates the relation between financial literacy level and gender of individuals. It was attempted to determine whether gender affects the level of financial literacy and what is the extent of this effect. In order to test this relation, an online survey was applied to 602 people living in Turkey with a randomly selected sample. A regression analysis was conducted with the obtained data to determine the existence of the relation and the Anova analysis was conducted additionally. Then, the direction and level of the data were found by the correlation analysis. The study found out which gender had more sufficient financial knowledge and determined the gender of the individuals who needed to receive finance education. In addition, the investment knowledge of men and women were compared and the effect of gender difference on financial literacy was determined. As a result of the analyses, it was concluded that gender has no significant effect on financial literacy, that the financial literacy is affected by financial education and that there will not be any difference between men and women if women are educated and equipped with financial information as a part of the society.
\end{abstract}

Keywords: Financial Literacy, Gender and Finance Education

Jel Codes: G20, G40, G41

Öz

Finansal okuryazarlık, bir bireyin temel finansal uygulamalar hakkında bilgi sahibi olarak karar verebilme yeteneğidir. Finansal okuryazarlık sadece birey için değil aynı zamanda bir ülkenin piyasalarının gelişmesi için de önem arz etmektedir. Bir ülkenin piyasalarını geliştirebilmek için en alt konumdaki bireyden başlayarak eğitim verilmelidir. Böylece; nitelikli finans eğitiminin verilmesi hem bireyi hem de o bireylerin ait olduğu ülkenin ekonomisinin gelişmesine katkıda bulunmaktadır.

$\mathrm{Bu}$ çalı̧̧mada bireylerin finansal okuryazarlık seviyesi ile cinsiyet arasındaki ilişki araştırılmıştır. Cinsiyetin finansal okuryazarlık seviyesini etkileyip etkilemediği eğer etkiliyorsa ne düzeyde etkilediği tespit edilmeye çalışılmıştır. Bu ilişkiyi test etmek için online olarak Türkiye'de ikamet eden 602 kişiye anket yapılmış ve örneklem tesadüfi olarak seçilmiştir. Elde edilen verilere regresyon analizi yapılarak ilişkinin varlığı belirlenmiş ve ayrıca Anova analizi yapılmıştır. Ardından veriler arasındaki ilişkinin yönü ve derecesi korelasyon analiziyle bulunmuştur. Çalıșmanın sonucunda kadınların mı erkeklerin mi finans bilgisinin daha yeterli olduğu ve finans eğitimi alması gereken bireylerin cinsiyetleri bulunmuştur. Ayrıca kadınlarla erkeklerin yatırım bilgileri de kıyaslanmış ve finansal okuryazarlık konusunda cinsiyet farklılığının etkisi olup olmadığı belirlenmiştir. Analizler sonucunda; cinsiyetin finansal okuryazarlık üzerinde anlamlı bir etkisinin olmadığı, finansal eğitimin finansal okuryazarlığı etkilediği, ayrıca kadınların toplumun parçası olarak eğitildiğinde ve finansal bilgi ile donatıldığında finansal okuryazarlık bağlamında kadın-erkek farkının olmayacağı sonucuna ulaşılmıştır.

Anahtar Sözcükler: Finansal Okuryazarlık, Cinsiyet ve Finans Eğitimi

Jel Kodu: G20, G40, G41

\footnotetext{
${ }^{1}$ This study is an extended and modified version of the paper presented at 1st INES Symposium in 2016.

2 Dr. Öğretim Üyesi, Aksaray Üniversitesi Sağllk Bilimleri Fakültesi Sağlık Yönetimi Bölümü, hasimbagci1907@ hotmail.com

3 Muğla Sitkı Koçman Üniversitesi Sosyal Bilimler Enstitüsü Muhasebe-Finansman Programı Doktora Öğrencisi, emrekahraman1410@hotmail.com
} 


\section{INTRODUCTION}

Financial literacy has become a new concept in the finance literature with globalization where individuals has more the financial freedoms. The rise of this concept is also directly related to the concept of behavioural finance. Following the concept of behavioural finance based on the financial freedom and self-decision of individuals, it has become essential for individuals to take correct financial decisions. The best decision for that will be to increase the financial literacy levels of individuals.

There are various definitions in the literature regarding the concept of financial literacy. According to Bodie, financial literacy refers to the development of the ability to take informed decisions on issues that are among the basic functions of a business including setting a budget, saving and investing, borrowing and lending, insuring and risk distribution (Bodie, 2006: 1). According to Lusardi, financial literacy refers to the knowledge of an individual on financial instruments and concepts so that he or she has the awareness to make the correct choice among the investment alternatives (Lusardi, 2006: 1). According to Mason and Wilson, financial literacy is the awareness of people on the basic financial concepts and their ability to make interpretation and evaluation based on their knowledge (Mason and Wilson, 2000: 31). According to Noctor, financial literacy is the ability to take effective decisions using correct information on the management and use of money (Noctor et al., 1992: 21-24). According to Servon and Kaestner, financial literacy is the ability of a person to understand and use financial concepts (Servon and Kaestner, 2008: 271).

A person who wishes to specialize on financial literacy first needs to possess 3 basic skills: the skill to look for information, the skill to evaluate information and the skill to benefit from information. The skill to look for information refers primarily to the knowledge of individuals on financial concepts and issues, and then obtaining the information that is suitable for circumstance. The skill to evaluate information is the ability of an individual to critically evaluate and interpret the information is suitable for circumstance. The skill to benefit from information is the ability to benefit from the available financial information so that correct and effective financial decisions can be taken (Wagland, 2006: 1-6).

Financial literacy has gained great importance with the free market economy. Generally, informed individuals become better consumers and therefore financial literacy levels should be increased so that the consumers can use correct financial services at correct times. With the increase of the level of financial literacy, people will be able to manage their moneys, reach to suitable financial services and take correct and effective investment decisions with comprehensive knowledge. Financial literacy is very important to reduce the future anxiety of families while future oriented financial planning may reduce the problems of families and prevent them from losing hope. In addition, the increase of low financial literacy level in developing countries will accompany to an increase of the welfare level of the people together with the effective investment decisions (Shockey, 2002: 61; Özçam, 2006: 19; Reyes, 2006: 82; Hathaway and Khatiwada, 2008: 1).

Financial literacy is very important for all societies and it has macroeconomic effects as well. Together with the increase in financial products and services, financial safety is compromised in societies with low financial literacy which endangers the financial future of that country. In the long term, financial literacy increases the welfare level of people as well as the demand to the financial products and services. Due to the education programs, people with low income level in a society should be provided with awareness on financial literacy. In addition, after the changes and developments in the insurance sector, an individual with low financial literacy level may make wrong choices. All these effects indicate that financial literacy affects a society as well as the individuals (Mandell, 2006: 1; Klein, 2007: 209; Altıntaş, 2008: 32; Willis, 2008: 2; Cole et al., 2009: 3). Trainings are organized in Turkey under certain projects to develop financial literacy. These projects are carried out under the leadership of the Association for Financial Literacy and Access (FODER). The target of Özlem DENIZMEN, the chairperson of this association, is to reach to 500 thousand students in 2017. The most important projects among them is the 3 Penny Banks education program which is still going on. "The 3 Penny Banks Financial Literacy Program", that has been carried out since the academic year of 2013 to 2014 with the cooperation of the Doğuş Group and Money Forecast and with the support of the Ministry of National Education, makes children happy and increases their learning desires through various education models. In addition, the project "I Can Manage My Money" aims to provide the young people in Turkey between the ages from 15 to 30 years with an education opportunity to support them in setting budgets of their personal financial resources and finance services (http://www.fo-der.org/category/hakkimizda/, 29.07.2016).

This study will measure the relation between financial literacy and gender. The problem of the study is whether there is a relation between financial literacy and gender, and whether they influence each other. The reason to conduct the study is the fact that the concept of financial literacy is new in the literature with limited number of studies on it. There is no study present in the national literature on the relation between financial literacy and gender. The study aims to contribute to the literature by comparing the financial literacy levels of both men and 
women and by determining the influence of gender. The basic goal of the study is to measure the effect of gender on financial literacy.

The subject of financial literacy is a new concept for the national literature while there are studies available in the foreign literature. National literature has limited number of studies on the subject. In their study in 2013, Dick and Jaroszek found that young families planned to increase their future income by taking long term loans but there were some deviations from rationality due to some limitations (Dick and Jaroszek, 2013: 6-13). In the study by Disney and Gathergood in 2011, they found that individuals with low financial literacy got loans with higher interest and longer term accompanied by subsequent difficulties in paying these loans back (Disney and Gathergood, 2011: 22-26). In his study in 2010, Hustan reduced financial literacy into 2 dimensions: understanding financial information and implementing it (Hustan, 2010: 296-316). Delevande found that there was a relation in the same direction between welfare level and financial literacy level and argued that it was because of the fact that individuals controlled themselves as their welfare increased and they were able to easily reach financial information (Delavande, 2008: 190). Murphy determined that education increased financial literacy and particularly the education of business administration was effective on this matter (Murphy, 2005: 478-488). There is a report drafted by the Organisation for Economic Cooperation and Development (OECD) in Turkey on the relation between financial literacy and gender, which is the subject of this article, however, there is no publication on the subject matter. There are various studies in the European countries with the conclusion that men are more successful in managing money than women (Chen and Volpe, 1998: 107-128; Worthington, 2004: 95; Mandell, 2008: 257-279; Cole et al., 2009: 117; OECD, 2013, p.1-12).

\section{LITERATURE STUDY}

The studies on the relation between financial literacy and gender are generally available in the foreign literature. There is no study found in the national literature measuring the effect of gender on financial literacy. In this context, the studies in the foreign literature are summarized in chronological order.

Chen and Volpe (2002) examined the differences of financial literacy and gender in their study with university students. In the study, it was found that women had less financial knowledge. There is a statistical and significant gender difference considering the factors including the class, rank, work experience and ages of the participants. In addition, it was stated that education and work experience had a significant effect on financial literacy regardless of gender. On the other hand, it was found that women were less willing in obtaining information on personal finance matters than men.

Fonseca, Mullen, Zamarro and Zissimpoulos (2012) used the data of RAND American Life Panel in their study on the role of marriage and difference among the couples between financial decisions and gender. They stated that the demographic qualities of men and women had no relation with the level of financial literacy, that education, income and marital status had a statistical effect on financial literacy and that decision making mechanism between the couples was related with education.

In their survey study with 1300 participants in Sweden, Almenberg and Dreber (2012) examined the relation between financial literacy and gender. They stated that women had less participation in stock markets and had a lower level of financial literacy than men. In addition, they stated that women took less risks than women and this risk attitude affected the level of financial literacy.

In their study in 14 countries, Atkinson and Messy (2012) measured the relation between the financial information, financial behaviour and financial attitude in countries, using the data in the International Financial Education Network study of OECD. According to the results of the study, it was determined that the lack of financial knowledge in all countries was high and that the financial behaviour and financial attitude were developing.

Filipiak and Walle (2015) studied in India the extent of the levels of financial information between men and women being influenced by the ways of being raised. One part of the study was conducted between the individuals who were living in patriarchal environments and the other part of the study was conducted between the individuals who were living in matriarchal environments. The study concluded that the women had less knowledge on financial literacy, instruments and applications than men. It was found that the women in patriarchal environments had lower financial literacy level than those in matriarchal environments, but there was no difference between the financial literacy levels of women and men living in matriarchal environments. English level, education, use of various resources like television and radio played an important role to explain this difference between women.

In their study conducted in Hong Kong, Yu, Wu, Chan and Chou (2015) examined the relation between financial literacy and gender difference with consideration of the factors including socio-demographical variables, social 
and psychological factors and retirement planning. As a result of the study, they stated that there was a gender difference in age, retirement savings, risk tolerance, calculation skill and financial knowledge and that it was necessary to apply development programs that were specific to women.

Barboza, Smith and Pesek (2016) studied the relation between gender, academic achievement and financial literacy level by using the data from 380 university students. They used a series of Probit model in their studies and measured the academic achievement with score average. As a result, they stated that gender and academic achievement had significant effects on financial literacy. They stated that the financial literacy levels of men were higher than women, that the individuals with higher score averages were more advantageous than those with low score averages and that the individuals with the lowest level of financial literacy were women and had low score averages.

Hasler and Lusardi (2017) studied the relation between financial literacy and gender in 143 countries using the data from the S\&P Global FinLit Survey. In general, it was stated that the financial literacy levels in the world were very low and it was emphasized that around 3,5 billion people in the world population had difficulty in understanding basic financial concepts. The most important point under the light of the survey data is that women had lower financial literacy level than men in the majority of countries. According to the worldwide data, gender difference affects the financial literacy rates in the developed economies such as France, Canada, Italy, United Kingdom, Germany, Japan and USA (G7 countries) and developing economies such as Russia, China, Brazil, South Africa and India (BRICS countries). The literacy rate is around 55\% in developed countries while the same rate is $28 \%$ in developing countries. As a result, financial information and skills vary significantly between the developed economies and the developing economies. In addition, the difference between financial literacy and gender occurs in both conditions regardless of the development levels of the economy. Gender differences are clearly seen in the G20 countries with similar economies (Australia, Argentina, Canada, China, Brazil, India, Germany, Indonesia, Italy, South Africa, South Korea, Saudi Arabia, Japan, Russia, Mexico, France, UK, USA and Turkey). In general, the financial literacy levels are higher in Canada, Australia, USA, UK and Germany. The financial literacy among men and women in UK, Japan, South Africa and China are at acceptable levels. On the other hand, the financial literacy levels due to gender difference in Australia, Canada, Italy, Brazil and Indonesia are higher than the other countries. In Turkey, this level is an average of the developing countries with women having a lower financial literacy level.

Adam, Boadu and Frimpong (2018) conducted a study among the retired people in Ghana and examined the relation between financial literacy and gender. Their survey covered information on budget, use of cash point, time value of money, insurance and account types with the participation of 334 individuals including 183 men and 151 women. In the end of the study, it was stated that men had higher level of knowledge in seven (7) of the ten questions in the survey and that women had higher level of knowledge in the remaining three (3) of the ten questions in the survey. The financial literacy level appeared to be in favour of men in all tests except the question on interest rate calculation. In addition, the fact that men had higher financial literacy levels was associated with the fact that older men had better calculation skills than women and it was stated that women had to work more on calculation skills.

Longobardi, Pagliuca and Regoli (2018) investigated the importance of the financial literacy level and gender difference of the Italian students. In their study using the PISA data, they stated that the Italian students had a lower financial literacy level compared to the students in the other countries. It is stated gender discrimination has a negative effect on the financial knowledge, skill and attitude of girls and boys. The level of financial literacy, school type, student performance and socio economic conditions play an important role in the awareness of financial decision making.

Arellano, Camara and Tuesta (2018) studied whether gender difference had an effect on financial literacy and the extent of this effect if any. In the study, boys and girls have different skills to become financially literate. In Spain, the gender based difference was reduced by 20 percent when students in the age of 15 years were guided according to their skills. In addition, the financial literacy difference between boys and girls was found statistically significant.

Çera and Tuzi (2018) studied the relation between financial literacy and gender in Albania. In their study, they used a survey covering financial literacy, attitude and behaviours. As a result of the study, they stated that there were gender based differences in financial decision making in spite of the common qualities. It was found that the young boys were better in coping with risks and with regards to financial knowledge compared to young women while the latter were more concerned in money management and spending.

Preston and Wright (2019) studied the relation between financial literacy and gender in Australia. In their study, they used the variables including age and education and found that these variables were insignificant to explain the gender difference. Profession, sector, industry, union membership and market condition only affect a section of 16 percent and the difference between the remaining major part doesn't have a significant explanation. 
Farrar, Moizer, Lean and Hyde (2019) studied the relation between sex, retirement plan and financial literacy using the logistic regression model with 516 male and female participants in England. As a result of their study, no relation was found between financial literacy and retirement plan and it was stated that women had lower levels in planning. In addition, it was stated that the gender difference didn't play a decisive role in retirement planning based on the variables including financial attitude and expectation.

\section{METHOD}

Online survey was applied to the individuals who constituted the sample of the study. The survey link that was created was sent to the e-mail addresses to the individuals with measures to prevent any individual from filling in more than one surveys. Survey data were analysed with the SPSS 20 program.

\section{Population of the Study}

The population of the study are all individuals living in Turkey with the potential of having financial literacy. However, a group from the population was selected since it was difficult to reach the population.

\section{Sample of the Study}

The sample of the study was randomly selected. No certain region limit was applied when selecting the sample and 601 people were selected randomly through the online surveys.

\section{Data Collection Instruments}

After the survey questions were determined, the survey was created from Google forms which is the online survey section of the Gmail application. Survey links were sent to the e-mail addresses and shared in the social media accounts. The number of the responded surveys and the responses were viewed in Google forms.

\section{Data Analysis}

The data were analysed through the SPSS 20 program. Non-parametric tests and correlation analyses were used since the data analysis didn't conform to the normal distribution.

\section{FINDINGS}

Table 1 shows the number of people participating in the survey and frequency tables.

Table 1. Frequency Analysis

\begin{tabular}{|c|c|c|c|c|}
\hline \multirow{6}{*}{ 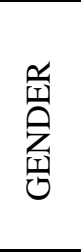 } & & & Frequency & Valid Percentage \\
\hline & & Men & 293 & 48,9 \\
\hline & & Women & 306 & 51,1 \\
\hline & & Total & 599 & 100,0 \\
\hline & Unanswered & & 2 & \\
\hline & Total & & 601 & \\
\hline \multirow{9}{*}{$\underset{⿱}{\mathbb{Z}}$} & & Below 20 & 33 & 5,5 \\
\hline & & $20-25$ & 207 & 34,6 \\
\hline & & $25-30$ & 132 & 22,1 \\
\hline & & $30-35$ & 87 & 14,5 \\
\hline & & $35-40$ & 56 & 9,4 \\
\hline & & Above 40 & 83 & 13,9 \\
\hline & & Total & 598 & 100,0 \\
\hline & Unanswered & & 3 & \\
\hline & Total & & 601 & \\
\hline \multirow{7}{*}{ 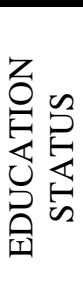 } & & Primary School & 23 & 3,8 \\
\hline & & High School & 104 & 17,4 \\
\hline & & Associate/Bachelor Degree & 317 & 53,0 \\
\hline & & Postgraduate & 154 & 25,8 \\
\hline & & Total & 598 & 100,0 \\
\hline & Unanswered & & 3 & \\
\hline & \multicolumn{2}{|l|}{ Total } & 601 & \\
\hline
\end{tabular}




\begin{tabular}{|c|c|c|c|c|}
\hline $\begin{array}{l}z \\
0 \\
0 \\
\text { w } \\
\frac{1}{1} \\
0 \\
\frac{1}{2} \\
0\end{array}$ & & $\begin{array}{l}\text { Student } \\
\text { Public servant } \\
\text { Self employed } \\
\text { Farmer } \\
\text { Tradesmen } \\
\text { Worker/Private Sector } \\
\text { Employee } \\
\text { Housewife } \\
\text { Retired } \\
\text { Other } \\
\text { Total } \\
\end{array}$ & $\begin{array}{c}209 \\
167 \\
16 \\
8 \\
13 \\
75 \\
29 \\
10 \\
74 \\
601\end{array}$ & $\begin{array}{c}34,8 \\
27,8 \\
2,7 \\
1,3 \\
2,2 \\
12,5 \\
4,8 \\
1,7 \\
12,3 \\
100,0 \\
\end{array}$ \\
\hline \multirow{10}{*}{ 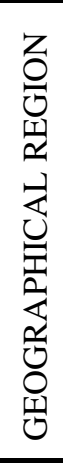 } & & Mediterranean region & 86 & 14,4 \\
\hline & & \begin{tabular}{|l|} 
Aegean region \\
\end{tabular} & 60 & 10,0 \\
\hline & & Black Sea region & 61 & 10,2 \\
\hline & & Marmara Region & 75 & 12,5 \\
\hline & & Central Anatolia region & 211 & 35,2 \\
\hline & & $\begin{array}{l}\text { South-eastern Anatolia } \\
\text { region }\end{array}$ & 58 & 9,7 \\
\hline & & Eastern Anatolia region & 48 & 8,0 \\
\hline & & Total & 599 & 100,0 \\
\hline & Unanswered & & 2 & \\
\hline & \multicolumn{2}{|l|}{ Total } & 601 & \\
\hline \multirow{8}{*}{ 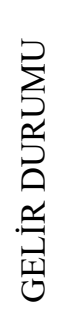 } & & Below 1000 & 185 & 31,3 \\
\hline & & $1000-2000$ & 106 & 17,9 \\
\hline & & $2000-3000$ & 106 & 17,9 \\
\hline & & $3000-4000$ & 96 & 16,2 \\
\hline & & Above 4000 & 98 & 16,6 \\
\hline & & Total & 591 & 100,0 \\
\hline & Unanswered & & 10 & \\
\hline & \multicolumn{2}{|l|}{ Total } & 601 & \\
\hline
\end{tabular}

As Table 1 indicates, 601 people participated in the survey. Each question had missing data. Only the question on profession was responded by everyone. The number of women and men participating in the analysis was approximate with a slight difference in favour of the women. The highest frequency data included the age difference between 20 to 25, education status including the graduates of associate degrees and bachelor degrees, profession given as student, the region named the Central Anatolia Region and the income status of $1000 \mathrm{TL}$ and less.

The followings were found as a result of the frequency analysis applied to the data loaded on the SPSS program: the gender percentage of the participants of the survey was slightly in favour of women; age range mainly consisted of the individuals in the age group between 20 to 25 years; regarding the education status, majority of the participants were graduates of associate degree/bachelor degree; profession was specified to be "student" by the majority; region was mainly Central Anatolia Region.

First, the types of tests conforming to the used dataset were determined. Therefore, conformance to normal distribution was determined. Homogeneity should also be checked even if the dataset conforms to the normal distribution. If the dataset has a normal distribution and is homogenous, then the parametric tests should be used. The normality test is conducted with the Kolmogorov-Smirnov test since the observation value of the data is $(\mathrm{N})$ $>30(\mathrm{~N}=601)$.

Table 2. One Sample Kolmogorov-Smirnov Test

\begin{tabular}{|c|c|c|c|}
\hline & & Your gender & $\begin{array}{c}\text { Do you know what Financial } \\
\text { Literacy is? }\end{array}$ \\
\hline $\mathrm{N}$ & & 599 & 597 \\
\hline Normal Parameters & Mean & 1,5109 & 1,5611 \\
\hline
\end{tabular}




\begin{tabular}{|ll|c|c|} 
& Std. Deviation &, 50030 &, 49666 \\
& Absolute &, 347 &, 373 \\
Most Extreme Differences & Positive &, 336 &, 310 \\
& Negative &,- 347 &,- 373 \\
Kolmogorov-Smirnov Z & & 8,486 & 9,106 \\
Asymp. Sig. (2-tailed) & &, 000 &, 000 \\
\hline
\end{tabular}

a. Test distribution is Normal.

b. Calculated from data.

As a result of this test, the normality distribution was denied since the significance value was $<0,05$. That is, dataset doesn't conform to normal distribution. Parametric tests can be applied by making the dataset conforming to normal distribution by certain methods, however, non-parametric tests were used in the present study without any changes on the dataset.

Problem 1: Is there a relation between gender and money management?

$\mathrm{H}_{0}$ : There is no relation between gender and money management. $\mathrm{H}_{1}$ : There is a relation between gender and money management.

Chi-square test was used to test this hypothesis and the results were shown in Table 3.

Table 3. Chi-square Test

\begin{tabular}{|l|c|c|c|c|c|}
\hline & Value & df & $\begin{array}{c}\text { Asymp. Sig. (2- } \\
\text { sided) }\end{array}$ & $\begin{array}{c}\text { Exact Sig. (2- } \\
\text { sided) }\end{array}$ & $\begin{array}{c}\text { Exact Sig. (1- } \\
\text { sided) }\end{array}$ \\
\hline Pearson Chi-Square & $63,363^{\mathrm{a}}$ & 1 &, 000 & & \\
Continuity Correction & 62,018 & 1 &, 000 & & \\
Likelihood Ratio & 64,755 & 1 &, 000 &, 000 &, 000 \\
Fisher's Exact Test & 63,256 & 1 &, 000 & & \\
Linear-by-Linear Association & 592 & & & & \\
N of Valid Cases & & & & \\
\hline
\end{tabular}

a. 0 cells $(0,0 \%)$ have expected count less than 5 . The minimum expected count is 109,13.

b. Computed only for a $2 \times 2$ table

The $\mathrm{H}_{0}$ hypothesis is rejected as the significance value is $0<0,05$ according to the Table 3 indicating that there is a relation between gender and money management. Data found as a result of this relation were shown in Table 4 .

Table 4. Crosstabs

\begin{tabular}{|l|l|c|c|c|}
\hline \multirow{3}{*}{ Gender } & \multicolumn{3}{|c|}{ Who is more successful in managing money? } \\
\cline { 2 - 5 } & Man & Woman & Man & Total \\
\cline { 2 - 5 } & Woman & $\% 36,5$ & $\% 70,3$ & $\% 49,2$ \\
\cline { 2 - 5 } & Total & $\% 100$ & $\% 29,7$ & $\% 50,8$ \\
\hline
\end{tabular}

Table 4 shows the crosstabs results as the existence of a significant relation between gender and money management was determined. According to Table 4, 36,5\% of men found women to be successful and $29,7 \%$ of women found men to be successful. It means that both men and women find themselves to be successful in 
money management. However, men find women to be a little more successful with a slight difference in percentage.

Problem 2: Is there a relation between financial literacy and finance education?

$\mathrm{H}_{0}$ : There is no relation between financial literacy and having finance education and $\mathrm{H}_{1}$ : There is a relation between financial literacy and having finance education.

Chi-square independence test was applied to test this hypothesis with the results shown in Table 5.

Table 5. Chi-Square Test

\begin{tabular}{|c|c|c|c|c|c|}
\hline & Value & df & $\begin{array}{l}\text { Asymp. Sig. (2- } \\
\text { sided) }\end{array}$ & $\begin{array}{l}\text { Exact Sig. (2- } \\
\text { sided) }\end{array}$ & $\begin{array}{l}\text { Exact Sig. (1- } \\
\text { sided) }\end{array}$ \\
\hline Pearson Chi-Square & $63,576^{\mathrm{a}}$ & 1 &, 000 & & \\
\hline Continuity Correction ${ }^{\mathrm{b}}$ & 62,217 & 1 &, 000 & & \\
\hline Likelihood Ratio & 64,169 & 1 &, 000 & & \\
\hline Fisher's Exact Test & & & &, 000 &, 000 \\
\hline Linear-by-Linear Association & 63,469 & 1 & 000 & & \\
\hline $\mathrm{N}$ of Valid Cases & 593 & & & & \\
\hline
\end{tabular}

a. 0 cells $(0,0 \%)$ have expected count less than 5 . The minimum expected count is 96,46 .

b. Computed only for a $2 \times 2$ table

The result was significant since the significance value was $0<0,05$ according to Table 5 and there is a significant relation between financial literacy and finance education. In addition, there is a significant relation between finance education, relevant education status, knowing financial investment instruments and derivative instruments, evaluating savings, knowing finance problems, taking advantage of the banking services, setting monthly budgets, monthly income, having savings and money management. Table 6 indicates the results of the relation between financial education and financial literacy.

Table 6. Crosstabs

\begin{tabular}{|c|c|c|c|c|}
\hline \multicolumn{5}{|c|}{ Did you have education in Economy / Finance? } \\
\hline \multirow{4}{*}{$\begin{array}{l}\text { Do you know what Financial } \\
\text { Literacy is? }\end{array}$} & & Yes & $\mathrm{No}$ & Total \\
\hline & Yes & $\% 65$ & $\% 31,4$ & $\% 43,8$ \\
\hline & No & $\% 35$ & $\% 68,6$ & $\% 56,2$ \\
\hline & Total & $\% 100$ & $\% 100$ & $\% 100$ \\
\hline
\end{tabular}

Table 6 shows the crosstabs of financial literacy and finance education. $65 \%$ of the people with financial literacy had finance education while $68,6 \%$ of the people without financial literacy didn't have finance education. This means that having finance education increases financial literacy.

Basic problem: Does financial literacy vary according to the gender?

Basic hypothesis: $\mathrm{H}_{0}$ : Financial literacy doesn't vary according to gender and $\mathrm{H}_{1}$ : Financial literacy varies according to gender.

Mann-Whitney U test was used to test this hypothesis. Results are shown in Table 7. 
Table 7. Test Statistics

\begin{tabular}{|l|c|}
\hline & Do you know what Financial Literacy is? \\
\hline Mann-Whitney U & 41152,500 \\
Wilcoxon W & 83638,500 \\
Z & $-1,709$ \\
Asymp. Sig. (2-tailed) &, 087 \\
\hline
\end{tabular}

a. Grouping Variable: your gender

Table 7 shows the results of the Mann-Whitney U test. Since the significance value is $0,087>0,05, \mathrm{H}_{0}$ hypothesis is acceptable and the results are not significant. That means that financial literacy doesn't vary according to gender.

Although financial literacy doesn't vary according to gender, the existence between them was subjected to correlation analysis with the direction and grade specified in Table 8.

Table 8. Correlation Analysis

\begin{tabular}{|c|c|c|c|c|}
\hline & & & Your gender & $\begin{array}{c}\text { Do you know what } \\
\text { Financial Literacy } \\
\text { is? }\end{array}$ \\
\hline Spearman's rho & $\begin{array}{l}\text { Your gender } \\
\text { Do you know what Financial } \\
\text { Literacy is? }\end{array}$ & $\begin{array}{l}\text { Correlation } \\
\text { Coefficient } \\
\text { Sig. (2-tailed) } \\
\mathrm{N} \\
\text { Correlation } \\
\text { Coefficient } \\
\text { Sig. (2-tailed) } \\
\mathrm{N}\end{array}$ & $\begin{array}{c}1,000 \\
\cdot \\
599 \\
, 070 \\
, 087 \\
595\end{array}$ & $\begin{array}{c}, 070 \\
, 087 \\
595 \\
1,000 \\
. \\
597 \\
\end{array}$ \\
\hline
\end{tabular}

Table 8 shows the results of the correlation analysis. Spearman correlation analysis was used instead of the Pearson correlation analysis since the dataset was non-parametric. As a result of the Spearman correlation analysis; the correlation coefficient was 0,07 although there was no significant difference between them $(0,087>$ $0,05)$. There is a positive but low correlation between gender and financial literacy.

\section{DISCUSSION}

The study includes some aspects that requires discussion. To mention about these aspects, first the reactions of the people to the survey that was drafted by the Google survey program through the Internet connection and the circumstances where they responded cannot be fully understood. The people are accepted to have provided clear and correct responses. Separate surveys to people may not be always sufficient, therefore having people fill in the same survey on different days and at different times may help in getting a better result. 


\section{RESULTS and RECOMMENDATIONS}

In all studies, financial literacy varies according to gender and the financial literacy level of men are higher than women. The reason is that men are more skilful in taking financial decisions and more eager to learn than women. Women take less risk and have lower desire to learn financial matters. It would be inaccurate to claim that "women have always less knowledge than men" for financial literacy that varies according to gender. Various factors are effective in the financial literacy level including education, age, income level of the person etc. Therefore, the present study examined the premise whether gender affects financial literacy under every circumstances and whether all women have less knowledge than men.

The aim of the study is to determine the presence of the relation between financial literacy and gender, and to see whether they vary according to each other. As a result of the analyses that were performed, no significant relation was found between financial literacy and gender and it was concluded that financial literacy didn't vary according to gender. A relation between financial literacy and finance education was determined and it was found that the people who had finance education had increased levels of financial literacy. In addition, there is a significant relation between financial literacy and education status, money management, setting monthly budgets, banking services, financial information and savings. It was concluded that the knowledge of individuals on both financial literacy and financial services increased in parallel to the education in the field of finance.

Further studies should aim at measuring financial literacy among businessmen and comparing the financial literacy of a group with financial education and a group without financial education. Finance education improves the financial literacy of individuals as well as making them equipped in financial products and services.

\section{REFERENCES}

ADAM, Anokye M., M. O. BOADU and S. FRIMPONG, (2018), "Does Gender Disparity in Financial Literacy Still Persist After Retirement? Evidence from Ghana”, International Journal of Social Economics, 45(1), 1828.

ALMENBERG, Johan and A. DREBER, (2012), Gender, Stock Market Participation and Financial Literacy, Working Paper Series in Economics and Finance.

ALTINTAŞ, Kadir Murat, (2008), "Bireysel Yatırımcılar Açısından Finansal Eğitimin Önemi”, Türk Sigorta Enstitüsü Vakfı Sigorta Araştırma ve İnceleme Yayınları-14.

ARELLANO, Alfonso, N. CAMARA and D. TUESTA, (2018), "Explaining the Gender Gap in Financial Literacy: The Role of Non-Cognitive Skills”, Economic Notes, 47(2-3), 495-517.

ATKINSON, Adele and F.-A. MESSY (2012), Measuring Financial Literacy: Results of the OECD/ International Network on Financial Education (INFE) Pilot Study, OECD Working Papers on Finance.

BARBOZA, Gustavo, C. SMITH and J. G. PESEK (2016), “Assessing Financial Literacy, Gender Gap and Cognitive Differences”, Journal of Financial Education, 42(3-4), 205-242.

BODIE, Zvi, (2006), A Note on Economic Principles and Financial Literacy, Networks Financial Institute at Indina State University Policy Brief.

CHEN, Haiyang and R. P. VOLPE, (1998). “An Analysis of Personal Financial Knowledge Among College Students". Financial Services Review, 7(2), 107-128.

CHEN, Haiyang and R. P. VOLPE, (2002), "Gender Differences in Personal Financial Literacy Among College Students”, Financial Services Review, 11, 289-307.

COLE, Shawn, T. SAMPSON and B. ZIA, (2009), Financial Literacy, Financial Decisions and the Demand for Financial Services: Evidence from India and Indonesia, Harvard Business School Working Paper.

ÇERA, Gentjan and B. TUZI, (2018), Does Gender Matter in Financial Literacy? A Case Study of Young People in Tirana, Scientific papers of the University of Pardubice. Series D, Faculty of Economics and Administration.

DELAVANDE, Adeline, S. ROHWEDDER and R. WILLIS, (2008), Preparation for Retirement, Financial Literacy and Cognitive Resources, Michigan Retirement Research Center Working Paper, No:190.

DICK, Christian and L. JAROSZEK, (2013), Knowing What Not to Do: Financial Literacy and Consumer Credit Choices, ZEW Discussion Paper No. 13-027, Mannheim. 
DISNEY, Richard and J. GATHERGOOD, (2011), Financial Literacy and Indebtedness: New Evidence for U.K. Consumers' Centre for Finance, Credit and Macroeconomics, Working Paper 11/05, University of Nottingham.

FARRAR, Sue, J. MOIZER, J. LEAN and M. HYDE, (2019), “Gender, Financial Literacy and Preretirement Planning in the UK”, Journal of Women \& Aging, 31(4), 319-339.

FILIPIAK, Ute and Y. M. WALLE, (2015). The Financial Literacy Gender Gap: A Question of Nature or Nurture?, Courant Research Centre: Poverty, Equity and Growth - Discussion Papers 176, Courant Research Centre PEG.

FODER, 2012-2016, http://www.fo-der.org/category/hakkimizda/, (Accession Date: 29.07.2016)

FONSECA, Raquel, K. J. MULLEN, G. ZAMARRO and J. ZISSIMOPOULOS, (2012), “What Explains the Gender Gap in Financial Literacy? The Role of Household Decision-Making", The Journal of Consumer Affairs, 46(1), 90-106.

HASLER, Andrea and A. Lusardi (2017), "The Gender Gap in Financial Literacy: A Global Perspective", Global Financial Literacy Excellence Center.

HATHAWAY, Ian and S. KHATIWADA, (2008), Do Financial Education Programs Work? Working Paper 08-03, Federal Reserve Bank of Cleveland.

HUSTON, Sandra J. (2010), "Measuring Financial Literacy”. The Journal of Consumer Affairs, 44(2), 296316.

KAHRAMAN, Yunus Emre, (2015), “Erciyes Üniversitesi Öğrencileri Üzerinde Finansal Okuryazarlık Araştırması”. Master Thesis, Muğla Sitkı Koçman Üniversitesi Sosyal Bilimler Enstitüsü, Muğla.

KLEIN, Valerie, (2007), “Making Sense of Financial Education” PhD Thesis, University of Pennsylvania.

LONGOBARDI, Sergio, M. M. Pagliuca and A. REGOLI, (2018), "Can Problem-Solving Attitudes Explain the Gender Gap in Financial Literacy? Evidence from Italian Students' Data”, International Journal of Methodology, 52(4), 1677-1705.

LUSARDI, Annamaria, (2006), Financial Literacy and Financial Education: Review and Policy Implications, Networks Financial Institute at Indina State University Policy Brief.

MANDELL, Lewis, (2006), Financial Literacy: If It's So Important, Why Isn't It Improving?, Networks Financial Institute at Indina State University Policy Brief.

MANDELL, Lewis, (2008), In Overcoming The Saving Slump: How To Increase The Effectiveness of Financial Education and Saving Programs, ed. Annamaria Lusardi, University of Chicago Press.

MASON, Carolynne L. J. ve R. M. S. WILSON, (2000), Conceptualising Financial Litercary, Loughborough University Business School.

MURPHY, Angela J. (2005), "Money, Money, Money: An Exploratory Study on the Financial Knowledge of Black College Students", College Student Journal, 39(3), 478-488.

NOCTOR, Michael, S. STONEY and, R. STRADLING (1992), Financial Literacy: A Discussion of Concepts and Competences of Financial Literacy and Opportunities for its Introduction into Young People's Learning, National Foundation for Educational Research Report for the National Westminster Bank. London, The United Kingdom.

OECD, (2013). "Kadınların ve Genç Kızların Finansal Farkındalık ve Finansal Eğitim İhtiyaçları”, OECD/INFE Politika Rehberi, Eylül 2013.

ÖZÇAM, Mustafa, (2006). "Yatırımcı Eğitimi: Dünya Uygulamaları ve Türkiye İçin Öneriler”, Sermaye Piyasası Araştırma Raporu, Ankara.

PRESTON, Alison C. and R. E. WRIGHT, (2019), "Understanding the Gender Gap in Financial Literacy: Evidence from Australia", Economic Record, 95(1), 1-29.

REYES, Ramon L. (2006), “The Psychological Meanings of Money”, PhD Thesis, Alliant International University.

SERVON, Lisa J. and R. KAESTNER, (2008), "Consumer Financial Literacy and the Impact of Online Banking on the Financial Behavior of Lower-Income Bank Customers”, Journal of Consumer Affairs, 42(2), 271-305. 
SHOCKEY, Susan S. (2002), “Low-Wealth Adults' Financial Literacy, Money Management Behaviors and Associated Factors, Including Critical Thinking", PhD Thesis, The Ohio State University.

WAGLAND, Suzanne, (2006), "Financial Literacy in the Context of Literacy in General", Fifth Australian Society of Heterodox Economists Conference, 1-6.

WILLIS, Lauren E. (2008), Evidence and Ideology in Assessing the Effectiveness of Financial Literacy Education, Legal Studies Paper No:2008-6 October, Loyola Law School, Los Angeles.

WORTHINGTON, Andrew C. (2004), The Distribution of Financial Literacy in Australia, Discussion Papers in Economics, Finance and International Competitiveness. No:185.

YU, K.-M., A. M. Wu, W.-S. CHAN and K. L. CHOU, (2015), "Gender Differences in Financial Literacy Among Hong Kong Workers”, Journal Educational Gerontology, 41(4), 315-326. 